\title{
Response of Cerebral Blood Volume to Changes in Arterial Carbon Dioxide Tension in Preterm and Term Infants
}

\author{
J. S. WYATT, A. D. EDWARDS, M. COPE, D. T. DElPY, D. C. MCCORMICK, A. POTTER, AND \\ E. O. R. REYNOLDS \\ Departments of Paediatrics and Medical Physics and Bioengineering, University College, \\ London, WCIE 6JJ, England
}

\begin{abstract}
The response of cerebral blood volume (CBVR) to a small induced change in arterial carbon dioxide tension was studied by near-infrared spectroscopy in 17 newborn infants born from 26 wk of gestation to term. All 17 infants were undergoing mechanical ventilation but had apparently normal brains. The CBVR per $\mathrm{kPa}$ change in arterial carbon dioxide tension within the range 3.9 to $9.6 \mathrm{kPa}$ was calculated from the change in total cerebral $\mathrm{Hb}$ concentration ([TCHb]) using the equation: $\Delta \mathrm{CBV}=\Delta[\mathrm{TCHb}] \times 0.89 /[\mathrm{H}]$ where $[\mathrm{H}]$ is the large vessel $\mathrm{Hb}$ concentration. A least-squares regression line with $95 \%$ confidence limits was derived for CBVR against gestational age. A highly significant linear increase in CBVR was found: mean $C B V R$ from the regression increased from $0.07 \mathrm{~mL} \cdot 100 \mathrm{~g}^{-1} \cdot \mathrm{kPa}^{-1}$ at 26 wk to $0.51 \mathrm{~mL} \cdot 100 \mathrm{~g}^{-1}$. $\mathrm{kPa}^{-1}$ at 40 wk. (Pediatr Res 29: 553-557, 1991)
\end{abstract}

\section{Abbreviations}

CBV, cerebral blood volume

CBVR, response of cerebral blood volume to changes in $\mathrm{PaCO}_{2}$

[Hb], cerebral deoxyhemoglobin concentration

$\left[\mathrm{HbO}_{2}\right]$, cerebral oxyhemoglobin concentration

MABP, mean arterial blood pressure

NIRS, near-infrared spectroscopy

$\mathrm{PaCO}_{2}$, arterial carbon dioxide tension

[TCHb], total cerebral $\mathrm{Hb}$ concentration

TCHbR, total cerebral $\mathrm{Hb}$ response to changes in $\mathrm{PaCO}_{2}$

The sensitivity of the intracranial blood vessels to changes in $\mathrm{PaCO}_{2}$ was first demonstrated by Wolff and Lennox (1) in 1930 using a pial window technique. Quantitative data on the response of cerebral blood flow to changes in $\mathrm{PaCO}_{2}$ were initially obtained by Kety and Schmidt (2) using the nitrous oxide clearance method. Since then, numerous studies in adults $(3,4)$, newborn infants $(5,6)$, and experimental animals $(7-10)$ have confirmed the positive relationship between cerebral blood flow and $\mathrm{PaCO}_{2}$ in normal individuals. Information on the response of $\mathrm{CBV}$ to changing $\mathrm{PaCO}_{2}$ is more limited (11-14), and only one report has been published involving newborn infants (15). That study, using NIRS, did not provide absolute quantitative data on CBV changes because of uncertainties about optical path length.

Received July 26, 1990; accepted January 14, 1991

Correspondence and reprint requests: Dr. J.S. Wyatt, Department of Paediatrics, Rayne Institute, 5 University Street. London WC1E 6JJ, England.

Supported by grants from the Medical Research Council, the Science and Engineering Research Council, the Wellcome Trust, the Wolfson Foundation. and Hamamatsu Photonics KK
Fluctuations in $\mathrm{PaCO}_{2}$ are common in infants undergoing intensive care. Information on the response of the cerebral circulation may be of considerable significance for improved understanding of the pathogenesis of hypoxic-ischemic brain injury and periventricular hemorrhage in these infants. NIRS, first described by Jobsis (16) in 1977, allows continuous, noninvasive, quantitative monitoring of cerebral blood volume (17, 18 ) in sick newborn infants. It is thus possible to determine at the bedside the response of the cerebral vasculature to changing $\mathrm{PaCO}_{2}$. The purpose of our present study was to measure by NIRS the effect on CBV of small alterations in $\mathrm{PaCO}_{2}$ in preterm and term infants with apparently normal brains who were undergoing intensive care. CBVR was defined as the change in $\mathrm{CBV}$ in $\mathrm{mL} \cdot 100 \mathrm{~g}^{-1} \cdot \mathrm{kPa}^{-1}$ resulting from an induced change in $\mathrm{PaCO}_{2}$ of 0.5 to $2 \mathrm{kPa}$.

\section{MATERIALS AND METHODS}

Subjects. Seventeen newborn infants who had been admitted to the Neonatal Unit of University College Hospital were studied; 12 were male and five were female. Their gestational ages ranged from 26 to 41 (median 29) wk and their birth weights from 856 to 3825 (median 1350) g. Their principle diagnoses are listed in Table 1. All infants were thought to have normal brains on the basis of clinical history and cranial ultrasound examination using Diasonics DSI (Diasonics Inc., Sunnyvale, CA) or ATL Ultramark 4 (Advanced Technology Laboratories, Germany). None was receiving medication likely to have an effect on the cerebral circulation. One of the infants subsequently died of chronic lung disease before discharge from hospital. Normality was confirmed in the remaining infants by clinical and ultrasound examination after discharge.

NIRS. Measurements of CBVR by NIRS were performed at the bedside at a postnatal age of 7 to 97 (median 21) h and continued for 1 to 6 (median 2.5) h. All infants were receiving mechanical ventilation at the time of the study. We previously described the portable apparatus we built for NIRS of the infant brain (19). This apparatus was used for studies in six infants, and a commercial prototype of this instrument (NIR1000; Hamamatsu Photonics KK) was used for the remaining 11 infants. The original instrument used near-infrared light at four wavelengths $(778,813,867$, and $904 \mathrm{~nm})$, and the commercial prototype used six wavelengths $(797,803,831,849,867$, and 908 $\mathrm{nm}$ ). A flexible fiberoptic bundle conveyed near-infrared light from laser diodes to the head. The end of the fiber bundle (the optode) was applied to the scalp at a site equidistant from the anterior fontanelle and the external auditory meatus. An identical bundle on the opposite side of the head conveyed transmitted light to a sensitive photomultiplier tube. In the six infants whose biparietal diameter exceeded 7 to $8 \mathrm{~cm}$, insufficient signals were obtained with this positioning, and the transmitting optode was 
therefore attached to the scalp just lateral to the anterior fontanelle, making an angle of approximately $90^{\circ}$ with the receiving fiber (orthogonal transmission). The distance between the optodes was measured using mechanical callipers. With orthogonal positioning of the fibers, the interoptode spacing was measured as the chord of the arc. To prevent interference from background illumination, the head was wrapped in a light-tight bandage. The total light power density emitted from the end of the transmitting fiber bundle was about $130 \mathrm{~W} \cdot \mathrm{m}^{-2}$, and the calculated power density at the skin surface was more than one order of magnitude below British Standards Institute safety limits (BS 4803), and considerably less at the brain surface.

A controlling computer calculated the changes in optical absorption at each wavelength and converted these into changes of $\left[\mathrm{HbO}_{2}\right]$ and $[\mathrm{Hb}]$. The $\mathrm{Hb}$ absorption coefficients, the derivation of appropriate algorithms, and the physical basis for this process have been described previously $(20,21)$. Data from the NIR 1000 were analyzed in a similar manner except that a standard leastsquares curve-fitting technique was used. Measurements were obtained at intervals of 15 to $20 \mathrm{~s}$ and were displayed instantaneously at the bedside and recorded on computer disk for subsequent analysis.

Due to the intense scattering of light in tissue, the optical path length was considerably greater than the interoptode spacing. On the basis of previous studies in postmortem infants (22), an optical path length of 4.4 times the measured interoptode distance was assumed. Arterial $\mathrm{O}_{2}$ tension and $\mathrm{PaCO}_{2}$ were estimated continuously using a transcutaneous monitor [Novametrix 850 (Novametrix Medical Systems, Wallingford, CT) or HewlettPackard 78834A (Hewlett-Packard Co., Palo Alto, CA)] calibrated against arterial blood gas measurement. An arterial or venous blood sample was taken for $\mathrm{Hb}$ estimation on the day of study. MABP was measured continuously from an indwelling arterial cannula or obtained using an oscillometric technique from an inflatable cuff (Dinamap 1846SX; Critikon, Irvine, CA).

After a period of baseline observations, an alteration in $\mathrm{PaCO}_{2}$ of $0.5-1.8 \mathrm{kPa}$ was induced over 5 to $20 \mathrm{~min}$ by a small change in ventilator rate. Whenever possible, the $\mathrm{PaCO}_{2}$ was maintained within the clinically accepted range $(4-7 \mathrm{kPa})$. If the $\mathrm{PaCO}_{2}$ was outside this range at the start of the study, the ventilator rate was altered to change the $\mathrm{PaCO}_{2}$ in the direction of normality. The inspired oxygen concentration was varied when necessary to keep the arterial $\mathrm{O}_{2}$ tension as constant as possible between 8 and $12 \mathrm{kPa}$. CBVR was estimated only if an adequate change in $\mathrm{PaCO}_{2}(>0.5 \mathrm{kPa})$ was observed and if the clinical condition of the infant remained stable during the maneuver.

Changes from baseline in $\left[\mathrm{HbO}_{2}\right]$ and $[\mathrm{Hb}]$ measured by NIRS
(Fig. 1) were analyzed by computer. Changes in [TCHb] in $\mu \mathrm{mol}$. $\mathrm{L}^{-1}$ could be calculated from the sum of $\left[\mathrm{HbO}_{2}\right]$ and $[\mathrm{Hb}]$ :

$$
\Delta[\mathrm{TCHb}]=\Delta\left(\left[\mathrm{HbO}_{2}\right]+[\mathrm{Hb}]\right)
$$

Changes in $[\mathrm{TCHb}]$ were plotted against $\mathrm{PaCO}_{2}$ for each study (Fig. 2), and a least-squares regression was performed to calculate the mean change in total $\mathrm{Hb}$ concentration per $\mathrm{kPa}$ change in $\mathrm{PaCO}_{2}$. In one infant, there appeared to be a flattening of the straight-line relationship between $\mathrm{CBV}$ and $\mathrm{PaCO}_{2}$ at higher $\mathrm{PaCO}_{2}$ values. In this infant, only the linear portion of the curve was used.

Changes in $\mathrm{CBV}$ in $\mathrm{mL} \cdot 100 \mathrm{~g}^{-1}$ were calculated from [TCHb] in $\mu \mathrm{mol} \cdot \mathrm{L}^{-1}$ from the formula:

$$
\Delta \mathrm{CBV}=\Delta[\mathrm{TCHb}] \cdot \mathrm{MW} /\left([\mathrm{H}] \cdot \mathrm{D} \cdot \mathrm{R} \cdot 10^{5}\right)
$$

where MW is the molecular weight of $\mathrm{Hb},[\mathrm{H}]$ is the large vessel $\mathrm{Hb}$ concentration in $\mathrm{g} \cdot \mathrm{dL}^{-1}, \mathrm{D}$ is brain density in $\mathrm{g} \cdot \mathrm{mL}^{-1}$, and $\mathrm{R}$ is the large vessel:cerebral hematocrit ratio. For this study, we assumed values of 64500 for MW, 1.05 for D (23) and 0.69 for $\mathrm{R}$ (24). These values give the formula:

$$
\Delta \mathrm{CBV}=\Delta[\mathrm{TCHb}] \times 0.89 /[\mathrm{H}]
$$

The CBVR (change in $\mathrm{CBV}$ per $\mathrm{kPa}$ change in $\mathrm{PaCO}_{2}$ ) in $\mathrm{mL}$. $100 \mathrm{~g}^{-1} \cdot \mathrm{kPa}^{-1}$ could then be calculated.

Our study was approved by the University College London Faculty of Clinical Science Committee on the Ethics of Clinical Investigation, and parental consent was obtained before each investigation.

\section{RESULTS}

Representative changes in $\left[\mathrm{HbO}_{2}\right],[\mathrm{Hb}]$, and $\left[\mathrm{HbO}_{2}\right]+[\mathrm{Hb}]$ during a transient alteration in $\mathrm{PaCO}_{2}$ are shown in Figure 1. Changes in [TCHb] plotted against $\mathrm{PaCO}_{2}$ in the same infant, together with the derived regression line to calculate CBVR, are shown in Figure 2. Values for TCHbR and CBVR in the 17 infants studied are given in Table 2. TCHbR ranged from 1.16 to $11.37 \mu \mathrm{mol} \cdot \mathrm{L}^{-1} \cdot \mathrm{kPa}^{-1}$, whereas CBVR ranged from 0.06 to $0.68 \mathrm{~mL} \cdot 100 \mathrm{~g}^{-1} \cdot \mathrm{kPa}^{-1}$.

When CBVR was plotted against gestational age at birth, it was apparent that there was a highly significant trend for CBVR to increase with gestational age, as illustrated in Figure 3. It was assumed that there was a linear relationship between these two variables, and the regression line and $95 \%$ confidence limits $(2.5$ and 97.5 percentiles) were calculated using the method of Armitage (25) (Table 3). The mean CBVR calculated from the

\begin{tabular}{|c|c|c|c|c|c|c|}
\hline $\begin{array}{l}\text { Infant } \\
\text { no. }\end{array}$ & $\begin{array}{c}\text { Gestation } \\
(w k)\end{array}$ & $\begin{array}{c}\text { Birth wt } \\
(\mathrm{g})\end{array}$ & $\begin{array}{l}\text { Postnatal age } \\
\text { at study (h) }\end{array}$ & Principle diagnosis & $\begin{array}{c}\mathrm{MABP} \\
(\mathrm{mm} \mathrm{Hg})\end{array}$ & $\begin{array}{c}\text { Initial } \mathrm{PaCO}_{2} \\
(\mathrm{kPa})\end{array}$ \\
\hline 1 & 26 & 879 & 9 & Hyaline membrane disease & 33 & 9.1 \\
\hline 2 & 27 & 856 & 24 & Hyaline membrane diseasc & 38 & 5.0 \\
\hline 3 & 27 & 890 & 24 & Hyaline membrane disease & 36 & 6.6 \\
\hline 4 & 27 & 1020 & 7 & Hyaline membrane disease & 30 & 4.9 \\
\hline 5 & 27 & 1030 & 28 & Hyaline membrane disease & 41 & 9.6 \\
\hline 6 & 28 & 1000 & 10 & Hyaline membrane disease & 32 & 6.1 \\
\hline 7 & 28 & 1137 & 7 & Hyaline membrane disease & 30 & 4.4 \\
\hline 8 & 28 & 1500 & 23 & Hyaline membrane discase & 43 & 4.9 \\
\hline 9 & 29 & 1350 & 8 & Hyaline membrane disease & 35 & 5.7 \\
\hline 10 & 31 & 1178 & 10 & Hyaline membrane disease & 28 & 6.2 \\
\hline 11 & 34 & 2100 & 10 & Hyaline membrane disease & 33 & 7.5 \\
\hline 12 & 36 & 2552 & 39 & Mcconium aspiration & 55 & 7.0 \\
\hline 13 & 36 & 3080 & 97 & Hyaline membrane disease & 50 & 7.2 \\
\hline 14 & 38 & 2700 & 65 & Listeria infection & 29 & 3.9 \\
\hline 15 & 40 & 2700 & 29 & Listeria infection & 59 & 6.8 \\
\hline 16 & 40 & 3825 & 21 & Meconium aspiration & 27 & 5.1 \\
\hline 17 & 41 & 3130 & 12 & Diaphragnatic hernia & 49 & 5.7 \\
\hline
\end{tabular}
regression increased from $0.07 \mathrm{~mL} \cdot 100 \mathrm{~g}^{-1} \cdot \mathrm{kPa}^{-1}$ at $26 \mathrm{wk}$ of

Table 1. Clinical details 


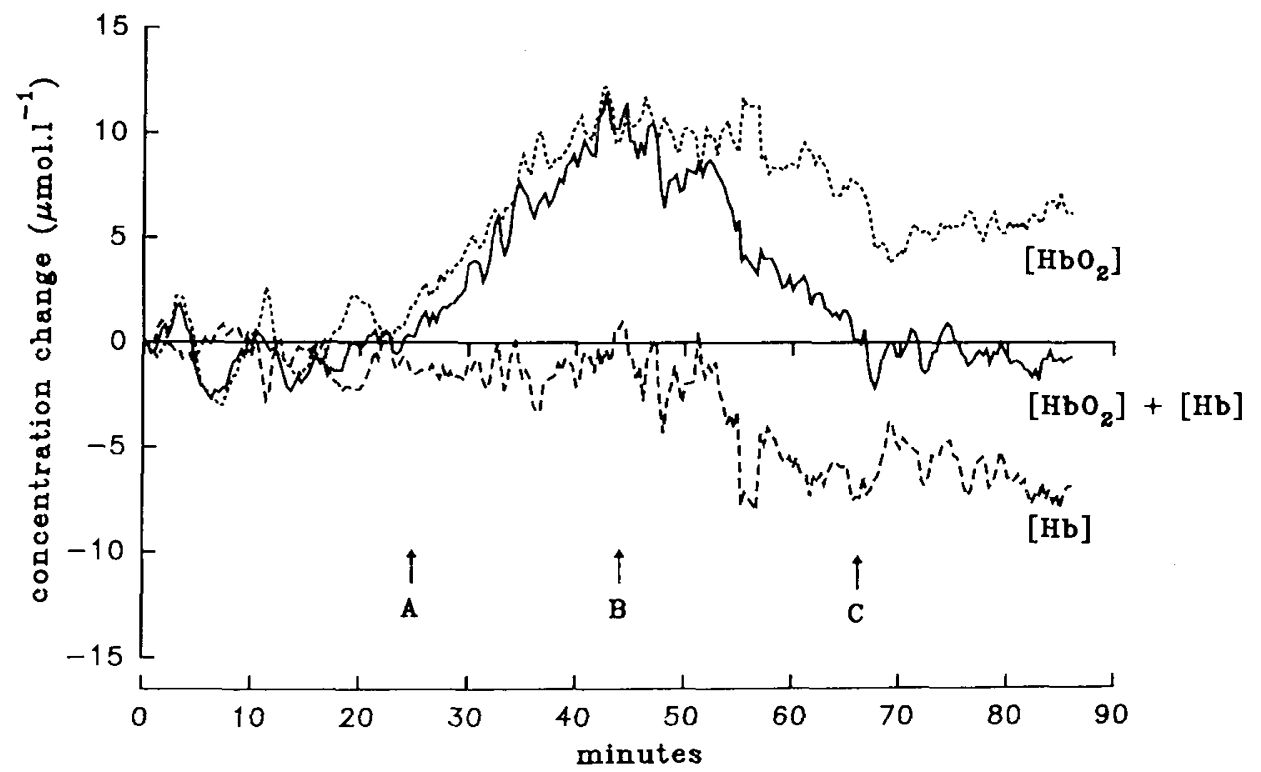

Fig. 1. Changes in $\left[\mathrm{HbO}_{2}\right],[\mathrm{Hb}]$, and $\left[\mathrm{HbO}_{2}\right]+[\mathrm{Hb}]$ during a transient alteration in $\mathrm{PaCO}_{2}$ in infant no. 17. The $\mathrm{PaCO}_{2}$ was $5.8 \mathrm{kPa}$ at $A$ and rose to $6.8 \mathrm{kPa}$ at $B$, returning to $5.9 \mathrm{kPa}$ at $C$. Arterial $\mathrm{O}_{2}$ tension rose slightly at $C$, causing a rise from baseline in [ $\left.\mathrm{HbO}_{2}\right]$ and a fall in [Hb].

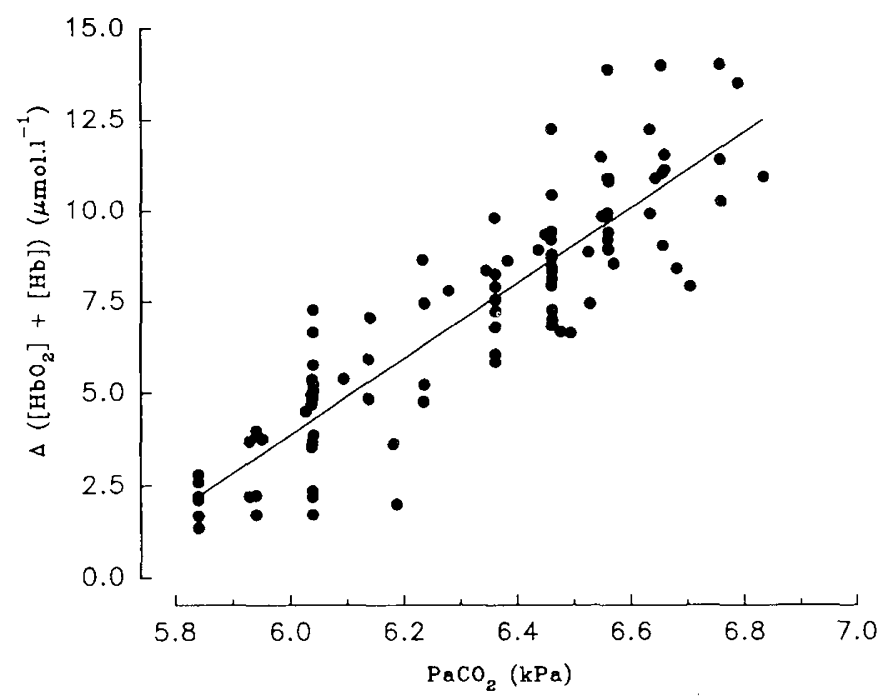

Fig. 2. Relation between changes in $\left[\mathrm{HbO}_{2}\right]+[\mathrm{Hb}]$ and $\mathrm{PaCO}_{2}$ in the same infant as in Figure 1, together with the derived regression line to calculate TCHbR, which was $11.37 \mu \mathrm{mol} \cdot \mathrm{L}^{-1} \cdot \mathrm{kPa}^{-1}$. The points represent 20 -s averages from the continuous records.

gestation to $0.51 \mathrm{~mL} \cdot 100 \mathrm{~g}^{-1} \cdot \mathrm{kPa}^{-1}$ at $40 \mathrm{wk}(\mathrm{CBVR}=0.031 \times$ gestational age $-0.745 ; r=0.82, p<0.0001)$.

Multiple stepwise regression analysis of the contributions of postnatal age and MABP to CBVR revealed no significant independent effect of either variable.

\section{DISCUSSION}

Validity of NIRS measurements. We have obtained the first quantitative data on the response of $\mathrm{CBV}$ to alterations in $\mathrm{PaCO}_{2}$ in newborn infants. However, the use of NIRS to measure CBV involves several simplifying assumptions. The head is regarded as an optically homogeneous compartment with a constant spatial distribution of $\mathrm{Hb}$ and a fixed mean hematocrit. Although $\mathrm{Hb}$ concentration is well known to vary in different regions of the brain, this will not have contributed a significant error to our calculation because of the highly light-scattering nature of brain tissue and the extended path taken by each photon.

We have assumed that the relation between optical path length and interoptode spacing was the same in infants with linear
Table 2. TCHbR and CBVR in infants

\begin{tabular}{rrr}
$\begin{array}{c}\text { Infant } \\
\text { no. }\end{array}$ & $\begin{array}{c}\text { TCHbR } \\
\left(\mu \mathrm{mol} \cdot \mathrm{L}^{-1}\right. \\
\mathrm{kPa})\end{array}$ & $\begin{array}{c}\mathrm{CBVR} \\
\left(\mathrm{mL} \cdot 100 \mathrm{~g}^{-1} \cdot \mathrm{kPa}^{-1}\right)\end{array}$ \\
\hline 1 & 2.85 & 0.17 \\
2 & 3.02 & 0.16 \\
3 & 4.09 & 0.19 \\
4 & 1.16 & 0.06 \\
5 & 4.74 & 0.35 \\
6 & 2.90 & 0.14 \\
7 & 1.45 & 0.09 \\
8 & 1.40 & 0.09 \\
9 & 2.42 & 0.18 \\
10 & 5.25 & 0.25 \\
11 & 3.00 & 0.15 \\
12 & 5.68 & 0.30 \\
13 & 6.04 & 0.32 \\
14 & 9.66 & 0.68 \\
15 & 9.94 & 0.55 \\
16 & 7.12 & 0.38 \\
17 & 11.37 & 0.63 \\
\hline
\end{tabular}

$\left(180^{\circ}\right)$ and orthogonal $\left(90^{\circ}\right)$ positioning of the optical fibers. This has been substantiated by recent data from time of flight measurement through the postmortem infant head (26). The possible error in path length is entirely negligible compared with the magnitude of the differences we have observed between term and preterm infants. We have also assumed that the relation between optical path length and interoptode distance was constant at different gestational ages. Although a small increase in path length with increasing gestational age might be anticipated (because of increased myelination), this is unlikely to cause an overestimation in CBVR of more than $10 \%$. This is negligible in comparison with the observed increase in CBVR of approximately $700 \%$ between 26 and 40 wk of gestation.

A further assumption was that optical path length remained constant during each study despite the observed changes in [TCHb]. In experimental animals, the optical path length at near-infrared wavelengths has been found to be remarkably constant despite gross changes in oxygenation and perfusion, and before and after death (27). The maximum variation in path length during these extreme changes of condition was $<9 \%$. Small fluctuations in [TCHb] can therefore be assumed to have exercised a negligible effect on path length. 


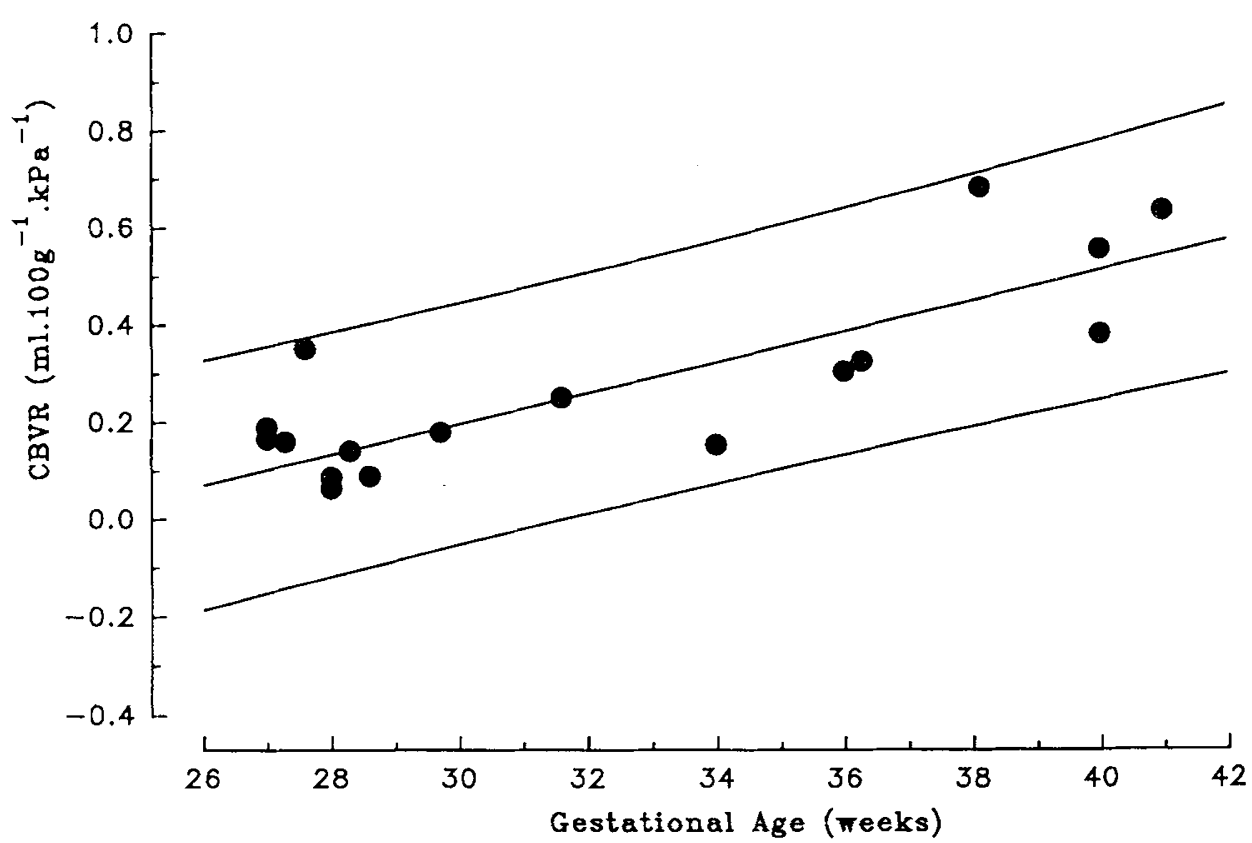

Fig. 3. CBVR in $\mathrm{mL} \cdot 100 \mathrm{~g}^{-1} \cdot \mathrm{kPa}^{-1}$ in the 17 infants plotted against gestational age. Least-squares regression line and $95 \%$ confidence limits $(2.5$ and 97.5 percentiles) are shown.

Table 3. Calculated regression and $95 \%$ confidence limits for $T C H b R$ and $C B V R$ with increasing gestational ages

\begin{tabular}{|c|c|c|c|c|c|c|}
\hline \multirow[b]{2}{*}{$\begin{array}{l}\text { Gestation } \\
\text { (wk) }\end{array}$} & \multicolumn{3}{|c|}{$\begin{array}{c}\operatorname{TCHbR}\left(\mu \mathrm{mol} \cdot \mathrm{L}^{-1}\right. \\
\left.\mathrm{kPa}^{-1}\right)\end{array}$} & \multicolumn{3}{|c|}{$\begin{array}{c}\mathrm{CBVR}\left(\mathrm{mL} \cdot 100 \mathrm{~g}^{-1}\right. \\
\left.\mathrm{kPa}^{-1}\right)\end{array}$} \\
\hline & Mean & $\begin{array}{l}\text { Upper } \\
\text { limit } \\
\end{array}$ & $\begin{array}{l}\text { Lower } \\
\text { limit }\end{array}$ & Mean & $\begin{array}{l}\text { Upper } \\
\text { limit }\end{array}$ & $\begin{array}{c}\text { Lower } \\
\text { limit }\end{array}$ \\
\hline 26 & 1.58 & 5.09 & -1.94 & 0.07 & 0.33 & -0.19 \\
\hline 28 & 2.62 & 6.06 & -0.83 & 0.13 & 0.38 & -0.12 \\
\hline 30 & 3.65 & 7.06 & 0.25 & 0.20 & 0.44 & -0.05 \\
\hline 32 & 4.69 & 8.09 & 1.30 & 0.26 & 0.51 & 0.01 \\
\hline 34 & 5.73 & 9.15 & 2.32 & 0.32 & 0.57 & 0.07 \\
\hline 36 & 6.77 & 10.23 & 3.31 & 0.38 & 0.64 & 0.13 \\
\hline 38 & 7.81 & 11.35 & 4.27 & 0.45 & 0.71 & 0.19 \\
\hline 40 & 8.85 & 12.48 & 5.21 & 0.51 & 0.78 & 0.24 \\
\hline 42 & 9.88 & 13.64 & 6.12 & 0.57 & 0.85 & 0.30 \\
\hline
\end{tabular}

The large vessel:cerebral hematocrit ratio has been demonstrated to change slightly with alterations in $\mathrm{PaCO}_{2}(28)$. We have estimated that this introduced an error of less than $3 \%$ in the conversion of changes in [TCHb] to changes in $\mathrm{CBV}$.

$\mathrm{Hb}$ saturation varies with changing $\mathrm{PaCO}_{2}$ due to an alteration in blood $\mathrm{pH}$ (the Bohr effect). This did not influence our calculations, however, as a change in $\mathrm{Hb}$ saturation would not affect the total $\mathrm{Hb}$ concentration. Although there were unknown and variable proportions of fetal and adult $\mathrm{Hb}$ in the blood of the infants studied, this had no significant effect on the results, inasmuch as the absorption spectra of fetal and adult $\mathrm{Hb}$ are virtually identical in the near-infrared region (29).

$C B V R$ measurement. For quantification of CBVR, we have made the simplifying assumption that the relation between $\mathrm{CBV}$ and $\mathrm{PaCO}_{2}$ is linear within the range of $\mathrm{PaCO}_{2}$ observed. Linearity in $\mathrm{CBF}$ response over a wide range of $\mathrm{PaCO}_{2}$ has been found by a number of workers $(3,4,8,9,12)$, but flattening of the response at extremes of $\mathrm{PaCO}_{2}$ has been observed $(6,7)$, suggesting a sigmoid relationship. It is likely that the relation between $\mathrm{CBV}$ and $\mathrm{PaCO}_{2}$ will be broadly similar.

In this study, we aimed to remain within the linear portion of the response curve. In one infant, we did observe apparent flattening of the curve at high $\mathrm{PaCO}_{2}$ values. In no infant was flattening of the CBVR observed at low $\mathrm{PaCO}_{2}$. This may have been because $\mathrm{PaCO}_{2}$ levels below $4 \mathrm{kPa}$ were not observed. Deliberate reduction of $\mathrm{PaCO}_{2}$ below this level was not attempted because of the possible risk from reduced cerebral oxygen delivery.

$C B V R$ in newborn infants. We have confirmed the physiologic response of $\mathrm{CBV}$ to changing $\mathrm{PaCO}_{2}$ and have demonstrated an increase in cerebrovascular reactivity with gestational age. In a previous study, we found no obvious relationship between total $\mathrm{CBV}$ in newborn infants and gestational age (18). Thus, the calculated percentage change in $\mathrm{CBV}$ per $\mathrm{kPa}$ increased from about $4 \%$ at 26 wk to about $25 \%$ at 40 wk of gestation. This effect is not apparent in data indicating normal $\mathrm{CO}_{2}$ responsivity of CBF (6) and CBF velocity (30) in extremely preterm infants. Thus, Greisen and Trojaborg (6) observed a mean CBF response to an induced change in $\mathrm{PaCO}_{2}$ of $67 \%$ per $\mathrm{kPa}$. The cerebrovascular response to changing $\mathrm{PaCO}_{2}$ is known to be attenuated by hypotension $(8,31,32)$. Inasmuch as MABP is frequently lower in very preterm infants than in more mature infants, the reduction in CBVR at younger gestational ages might be secondary to hypotension. However, multiple analysis of variance of our data failed to reveal any independent effect of MABP on CBVR.

The values for CBVR obtained in full-term infants correspond closely with those obtained by Greenberg et al. (14) from adult human volunteers using radiolabeled erythrocytes. This group determined a mean value for CBVR of $0.049 \mathrm{~mL} \cdot 100 \mathrm{~g}^{-1} \cdot$ torr $^{-1}$, equivalent to $0.37 \mathrm{~mL} \cdot 100 \mathrm{~g}^{-1} \cdot \mathrm{kPa}^{-1}$.

The physiologic mechanisms underlying the cerebrovascular response to carbon dioxide tension have not yet been fully elucidated, despite numerous investigations. The direct action of $\mathrm{CO}_{2}$ and various other mediators, such as perivascular $\mathrm{pH}$ and bicarbonate ion, on the cerebral vessel wall remains controversial, and prostanoids have been recently implicated (33). Indomethacin, a prostaglandin synthetase inhibitor, has been found to abolish this response in preterm infants (34), as well as in rats (35) and gerbils (36), although not in some other experimental animals (37). It is possible that alterations in the concentrations of prostanoids in brain tissue or vessel wall may account for the effect of gestational age on CBVR, but to our knowledge no data are available from human infants.

It is not known what are the relative contributions of the arterial, capillary, and venous compartments to the change in $\mathrm{CBV}$ induced by carbon dioxide. Inasmuch as increased $\mathrm{PaCO}_{2}$ 
was invariably associated with a rise in $\left[\mathrm{HbO}_{2}\right]$ but little change in $[\mathrm{Hb}]$, it is likely that the principle change in blood volume occurs in the arteriolar and capillary circulation. Further studies will be necessary to address this question.

Hypoxic-ischemic brain injury may occur in newborn infants if the $\mathrm{PaCO}_{2}$ is excessively low, causing reduced cerebral perfusion (38). Our data suggest that full-term infants have much greater cerebrovascular sensitivity to $\mathrm{PaCO}_{2}$ than preterm infants, and thus they may be particularly at risk of brain injury from hypocapnia. Inadvertent hypocapnia can readily occur in infants undergoing mechanical ventilation, especially when the lungs are relatively normal, allowing good gas exchange.

Acknowledgments. The authors thank Dr. Denis Azzopardi, Dr. Fenella Kirkham, Dr. Simon Roth, Clare Thorn, P. van der Zee, and the staff of the Neonatal Unit and the Department of Medical Physics and Bioengineering for their help.

\section{REFERENCES}

1. Wolff HG, Lennox WG 1930 The cerebral circulation: XII. The effects on pia vessels of variations in the $\mathrm{O}_{2}$ and $\mathrm{CO}_{2}$ content of the blood. Arch Neurol Psychiatry Chicago 23:1097-1120

2. Kety SS. Schmidt CF 1948 The effects of altered arterial tensions of carbon dioxide and oxygen on cerebral blood flow and cerebral oxygen consumption of normal young men. J Clin Invest 27:484-491

3. Alexander SC. Wollman H, Cohen PJ, Chase PE, Behar M 1964 Cerebrovascular response to $\mathrm{PaCO}_{2}$ during halothane anesthesia in man. J Appl Physio 19:561-565

4. Wyper DJ, Lennox GA, Rowan JO 1976 Two minute slope inhalation technique for cerebral blood flow measurement in man. J Neurol Neurosurg Psychiatry 39:147-151

5. Leahy FAN, Cates D, MacCallum M, Rigatto $\mathrm{H} 1980$ Effect of $\mathrm{CO}_{2}$ and $100 \%$ $\mathrm{O}_{2}$ on cerebral blood flow in preterm infants. J Appl Physiol 48:468-472

6. Greisen G, Trojaborg W 1987 Cerebral blood flow, $\mathrm{PaCO}_{2}$ changes and visual evoked potentials in mechanically ventilated preterm infants. Acta Paediatr Scand 76:394-400

7. Reivich M 1964 Arterial $\mathrm{PCO}_{2}$ and cerebral haemodynamics. Am J Physiol 206:25-35

8. Harper AM, Glass HI 1965 Effect of alterations in the arterial carbon dioxide tension on the blood flow through the cerebral cortex at normal and low arterial pressures. J Neurol Neurosurg Psychiatry 28:449-452

9. Alberti E, Hoyer S, Hamer J, Stoeckel H, Packschiess P, Weinhardt F 1975 The effect of carbon dioxide on cerebral blood flow and cerebral metabolism in dogs. Br J Anaesth 47:941-947

10. Kummer RV 1984 Local vascular response to change in carbon dioxide tension. Long term observation in the cat's brain by means of the hydrogen clearance technique. Stroke 15:108-114

11. Smith AL. Neufeld GR, Ominsky AJ, Wollman H 1973 Effect of arterial $\mathrm{CO}_{2}$ tension on cerebral blood volume, mean transit time, and vascular volume. J Appl Physiol 31:701-707

12. Phelps ME. Grubb RL, Ter-Pogossian MM 1973 Correlation between PaCo and regional cerebral blood volume by X-ray fluorescence. J Appl Physiol 35:274-280

13. Grubb RL, Raichle ME, Eichling JO, Ter-Pogossian MM 1974 The effects of changes in $\mathrm{PaCO}_{2}$ on cerebral blood volume, blood flow, and vascular mean transit time. Stroke 5:630-639

14. Greenberg JH, Alavi A, Reivich M, Kuhl D. Uzzell B 1978 Local cerebral blood volume response to carbon dioxide in man. Circ Res 43:324-331

15. Pryds O. Greisen G, Skov LL, Friis-Hansen B 1990 Carbon dioxide related changes in cerebral blood volume and cerebral blood flow in mechanically ventilated preterm neonates. Comparison of near infrared spectrophotometry and 133 xenon clearance. Pediatr Res 27:445-449
16. Jobsis FF 1977 Noninvasive infrared monitoring of cercbral and myocardial sufficiency and circulatory parameters. Science 198:1264-1267

17. Wyatt IS, Cope M, Delpy DT, Wray S, Reynolds EOR 1986 Quantification of cerebral oxygenation and hacmodynamics in sick newborn infants by near infrared spectrophotometry. Lancet 2:1063-1066

18. Wyatt JS, Cope M, Delpy DT, Richardson CE, Edwards AD, Wray SC. Reynolds EOR 1990 Quantitation of cerebral blood volume in newborn human infants by near infrared spectroscopy. $J$ Appl Physiol 68:1086-1091

19. Cope M, Delpy DT 1988 A system for long term measurement of cerebral blood and tissue oxygenation in newborn infants by near-infrared transillumination. Med Biol Eng Comput 26:289-294

20. Wray S, Cope M, Delpy DT, Wyatt JS, Reynolds EOR 1988 Characterization of the near infrared absorption spectra of cytochrome aa 3 and hacmoglobin for the non-invasive monitoring of cerebral oxygenation. Biochim Biophys Acta 933:184-192

21. Cope M, Delpy DT, Reynolds EOR, Wray S. Wyatt J, van der Zee P 1988 Methods of quantitating cerebral near infrared spectroscopy data. Adv Exp Med Biol 222:183-189

22. Wyatt JS, Cope M, Delpy DT, van der Zee P, Arridge S, Edwards AD, Wray SC, Reynolds EOR 1989 Measurement of optical pathlength for cerebral near-infrared spectroscopy in newborn infants. Dev Neurosci 12:140-144

23. Nelson SR, Mantz ML, Maxwell JA 1971 Use of specific gravity in the measurement of cerebral edema. J Appl Physiol 30:268-271

24. Lammertsma AA, Brooks DJ, Beaney RP, Turton DR, Kensett MJ, Heather JD, Marshall J, Jones T 1984 In vivo measurement of regional cerebral haematocrit using positron emission tomography. J Cereb Blood Flow Metab $4: 317-322$

25. Armitage P 1971 Statistical Methods in Medical Research. Blackwell, London. p 163

26. van der Zee P, Cope M, Arridge SR, Essenpreis M, Potter LA, Edwards AD Wyatt JS, McCormick DC, Roth SC, Reynolds EOR. Delpy DT 199! Experimentally measured optical pathlengths for the adult head, calf and forearm and the head of the newborn infant as a function of inter optode spacing. Adv Exp Med Biol (in press)

27. Delpy DT, Cope M, van der Zee P, Arridge S, Wray S, Wyatt JS 1988 Estimation of optical pathlength through tissue by direct time of flight measurement. Phys Med Biol 33:1433-1442

28. Sakai F Nakazawa K, Tazaki Y Katsumi I, Hino $H$ Igarashi $H$, Kanda T 1985 Regional cerebral blood volume and hematocrit measured in normal human volunteers by single-photon emission computed tomography. J Cereb Blood Flow Metab 5:207-213

29. Mendelson Y, Kent YC 1989 Variations in optical absorption spectra of adult and fetal haemoglobin and its effect on pulse oximetry. IEEE Trans Biomed Eng 36:844-848

30. Levene MI, Shortland D, Gibson N, Evans DH 1988 Carbon dioxide reactivity of the cerebral circulation in extremely preterm infants: cffects of postnatal age and indomethacin. Pediatr Res 24:175-179

31. Gregory P, Ishikawa T, McDowall DG $1981 \mathrm{CO}_{2}$ responses of the cercbra circulation during drug-induced hypotension in the cat. J Cereb Blood Flow Metab 1:195-201

32. Artru AA 1985 Cerebral vascular responses to hypocapnia during nitroglycerininduced hypotension. Neurosurgery $16: 468-472$

33. Wagerle LC, Mishra OP 1988 Mechanisms of $\mathrm{CO}_{2}$ response in cerebral arteries of the newborn pig: role of phospholipase, cyclooxygenase and lipooxygenase pathways. Circ Res 62:1019-1026

34. Edwards AD, Wyatt JS, Richardson CE, Potter A, Cope M, Delpy DT, Reynolds EOR 1990 Effects of indomethacin on cerebral haemodynamics and oxygen delivery investigated by ncar infrared spectroscopy in very preterm infants. Lancet 335:1491-1495

35. Dahlgren N, Nilsson B, Sakabe T, Siesjo BK 1981 The effect of indomethacin on cerebral blood flow and oxygen consumption in the rat at normal and increased carbon dioxide tensions. Acta Physiol Scand 111:475-485

36. Crockard A. Ianotti F, Ladds G 1982 Cerebrovascular effects of prostaglandin inhibitors in the gerbil. J Cereb Blood Flow Metab 2:67-72

37. Busija DW 1983 Role of prostaglandins in the response of the cerebral circulation to carbon dioxide in conscious rabbits. J Cereb Blood Flow Metab 3:376-380

38. Greisen G, Munck H, Lou H 1987 Severe hypocarbia in preterm infants and neurodevelopmental deficit. Acta Paediatr Scand 76:401 404 